\title{
Abandoned Children and Population Genetics: The Cases of Iggio and Tiola
}

\author{
S. Mazzoni ${ }^{1}$, L. Nicolini ${ }^{2}$, F. Tagliavini ${ }^{2}$, M. Manfredini $i^{3-*}$ \\ 1 Department of Economics of the University of Sassari \\ ${ }^{2}$ Faculty of Arts and Philosophy of the University of Modena and Reggio Emilia. E-mail: luciano_nicolini@iol.it \\ ${ }^{3}$ Department of Genetics, Anthropology, and Evolution of the University of Parma \\ * The authors share the responsibility of the entire manuscript
}

KEYWORDS: marriage, endogamy, foundlings.

\section{Introduction}

The critical reading of the main works on population genetics leads to the consideration that the genetic structure of the Italian populations has not changed strikingly in the period that goes from the Iron Age to the mid-20 $0^{\text {th }}$ century (when, in connection with industrialization, mass migrations occurred from the South toward northern Italy). On the contrary, recent studies induce to believe that, at least in some cases, continuity can be traced much further back in time.

Francalacci et al. (2006) have studied a sample of over 500 Y-chromosomes of individuals coming from three different areas of Sardinia, determining their belonging to haplotypes defined by SNP and STR. The results show a relative homogeneity of the Sardinian population, and lead us to believe that its genetic inheritance contains a preponderant pre-Neolithic component. Again based on the study of polymorphisms of the Y-chromosome, Sanna et al. (2006) have estimated that approximately $60 \%$ of Sardinian Y-chromosomes derives from an influx of migrants that occurred between the Upper Paleolithic and the Mesolithic. Tofanelli et al. (2005) have typed 7 biallelic loci and 11 STR systems of the non-recombinant region of the Y-chromosome in 54 unrelated donors who have resided for at least two generations in Garfagnana, an area included between the upper and middle valley of the Serchio River: in their genetic inheritance, the pre-Neolithic component proved to be preponderant. Di Gaetano et al. (2001), when characterizing some Italian populations through 16 biallelic polymorphisms of the non-recombinant region of the Y-chromosome, noticed, in Sicily, traces of the ancient Greek colonization and analogies with Calabria and Greece itself.

One summary explanation for these surprising persistencies can be provided by the statement of fact that in the cities, where the people who during the course of the centuries invaded Italy tended to settle, families would extinguish rapidly, thus favoring constant repopulation of the urban centers by the immigrants of the neighboring countryside, mainly inhabited by the decedents of the ancient native populations. This phenomenon is known and it has been observed since a long time also in other
European countries (Woods, 2003). This would therefore have resulted in a continuous influx of people from the countryside to the closest cities, while a population flow in the opposite direction would have been extremely weak. The cases of lggio (in the province of Parma) and Tiola (in the province of Bologna), rural parishes in which it was possible to notice, with reference to the $19^{\text {th }}$ century, a considerable number of marriages between locals and foundlings mainly coming from urban centers, make the context more complicated than one may think. It was therefore deemed suitable to analyze them using parish registers and, starting from the latter, attempt to understand what impact the practice of entrusting foundlings to peasant families could have had on the genetic structure of the population.

\section{Materials and Methods}

During the course of the centuries, many newborns were abandoned in the cities but also the countryside, so much so that in the 1800 s the phenomenon touched $3 \%$ of the births that took place in Italy (Kertzer et al., 1997). In this context, an important role was played by the hospices assigned to gather, care for and later place the foundlings in society. The hospices would send their beneficiaries to outside nurses, often residents of rural areas, and paid them - at least during the child's first year of life - more than they would earn working in the fields (Sigle et al., 2000). Payments ended when the person was able to support himself economically. Females, however, were more protected compared to males and usually had to be supported until marriage (Kertzer, 1999).

The rich documentation preserved in the hospices was widely used by historians whom, however, dealt more with the foundling phenomenon rather than the fate of the foundlings, which was much more complicated to assess due to the difficulty to reconstruct the life histories of foundlings. One thing is certain, the mortality rate of the latter reached very high levels, as recalled by Bussini (1991) in the case of Todi where, at the beginning of the 1800s, only $30 \%$ lived beyond the age of twelve. Some were able to integrate with the communities that took them in, yet it is not clear how many of them married individuals belonging to the latter, thus enriching, with their offspring, genetic variability. 
During the course of this research, the marriage behavior of foundlings entrusted to the care of rural families was studied using the parish registers of Iggio, a hillside village located in the municipality of Pellegrino Parmense, and Tiola, an upper hillside parish of the municipality of Castello di Serravalle, both characterized by a high percentage of marriages between locals and foundlings. With reference to the historical period that goes from the Restoration following the Napoleonic period up to the "Concordato" (Agreement) between the Italian State and the Catholic Church, the following were taken into consideration:

- the trend of the marriage rate and of the first marriage rate;

- the trend of the percentage of marriages with at least one foundling;

- the mean age of the males and females at their first marriage;

- the trend of the percentage of endogamous marriages with reference to residence (calculated, separately, for marriages with at least one foundling and for marriages without foundlings);

- the trend of the median marriage distance, measured on the road, of exogamous marriages with reference to residence (again calculated, separately, for the two types of marriages).

Finally, using the data provided by the website italia. indettaglio.it, mapping was performed of the municipalities of Emilia-Romagna in which the surnames that are for sure attributable to descendants of foundlings prove to be more frequent and, in comparison with the population residing in the individual municipalities, a calculation has been made of the percentage of individuals with said surnames over the total inhabitants.

\section{Results}

The marriage rates, in both parishes considered, do not seem to differ in any considerable way from those of their respective provinces: what characterizes them is the high percentage of marriages that have involved at least one foundling, a percentage that, in the second half of the 1800 s, was around $25 \%$ of the total. In approximately half of these marriages, the foundling was a male: therefore there seems to be no gender preference.

The mean age at the first marriage, among the female foundlings who married in Iggio, was lower than that of the women originally from that village, and contributed to lowering the general average (Mazzoni and Manfredini, 2005). Consistently, even in Tiola the mean age at the first marriage is, for females, slightly lower than the one registered in other areas with similar characteristics (Tagliavini and Nicolini, 2011). The datum was interpreted as being a consequence of the strong desire of the female foundlings to create their own families: in fact, the alternative involved returning to the hospice, where they could be supported, losing however the opportunity for an independent life (Kertzer and Sigle, 1998).

In both parishes a considerable tendency toward exogamy was noticed: in Tiola the percentage of endogamous marriages exceeds $50 \%$ only in the $1910-19$ ten-year time period; in Iggio, for the entire second half of the 1800 s, it is around $60 \%$. These values are quite low for the times, especially for hilly communities, which prove to be even lower if, among endogamous marriages, one does not take into account those involving at least one foundling. The median marriage distance in Tiola, in the second half of the 1800 s, is around 7 kilometers, and in Iggio around 12. The datum does not change considerably if exogamous marriages that include foundlings are considered separately: a further indication that, in the areas studied, there was no particular prejudice toward them.

Up until the middle of the 1800s, foundlings were given characteristics surnames: this is the case of "Tanzi" in Parma and "Degli Esposti" in Bologna. If one considers the municipalities of the province of Bologna in which the surname "Degli Esposti" is among the most frequent, it can be established that these places are located in the hilly area south-west of the provincial capital. In the province of Parma, the distribution of the surname Tanzi is similar. The unique concordance has lead to the mapping throughout the entire Emilia-Romagna region - of the municipalities in which one of the surnames given to foundlings up to the middle of the $19^{\text {th }}$ century appears among the five most frequent, that is to say mapping of the municipalities that can be considered, at least with reference to that period, the most oriented toward welcoming foundlings. For this purpose, only the most characteristics and widespread names were considered: Tanzi, Incerti,Venturelli, Degli Esposti, Casadio and Casadei (Fig. 1). In a first approximation, the surnames Venturi and Ventura were not considered, though quite widespread and, very probably, given to foundlings. All the municipalities in which one of the six surnames considered is among the five most frequent are in the hill area or near it, and the situation does not change if one considers the remaining two surnames.

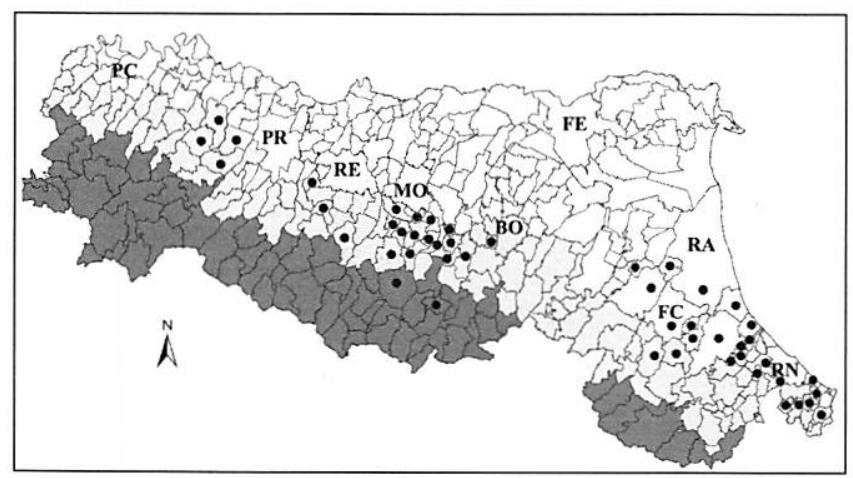

Fig. 1. Emilia-Romagna. Distribution of the municipalities in which one of the surnames given to foundlings up to the middle of the $19^{\text {th }}$ century appears among the five most frequent. In white, the plain municipalities, in light grey the hill municipalities, and in dark grey the mountain municipalities.

The attempt was then made to calculate the percentage of bearers of the six characteristic surnames over the total resident population as of the December 31, 2009: the results obtained in the 49 mapped municipalities vary between 0.4 and $2.2 \%$. Starting from the 1800 s, these 
surnames were no longer given, and the custom of giving foundlings an imaginary name began: it is therefore not possible to directly estimate the overall contribution provided by foundlings to the genetic inheritance of the populations of the municipalities mapped. It is however reasonable to believe that, in most of them, it does not exceed $5 \%$ of the total.

In fact, even where the percentage of bearers of the six surnames is today around $2 \%$, it is difficult to think, on the basis of what is known of the exposition fenomenon (Corsini, 1976; Da Molin, 1982), that the the contribution provided by foundlings in the following period ever exceeded $3 \%$.

It comes natural to ask oneself if said (relatively low) percentage is explainable on the basis of the limited impact of marriages between locals and foundlings (frequent in parishes such as Iggio and Tiola, but much less in others) or rather in the dilution of their contribution that occurred in the past one hundred years characterized, as mentioned, by wide range migrant movements. To answer this question, seven among the mapped municipalities were randomly chosen, and in each of these, using registry office documents, a calculation was made of the percentage of people entering into marriage who bore one of the six surnames over the total, with reference to the 191019 decade. The results are summarized in Table 1: in all the municipalities included in the sample (except for Santarcangelo) the percentage of bearers of the surnames considered, during the course of the past one hundred years, has been reduced to half, leading one to think that in them, and more in general in the hilly area of EmiliaRomagna, the genetic structure of the population has changed quite considerably. in the second half of the $19^{\text {th }}$ century, about $25 \%$ of the total.The study of the distribution of surnames given to foundlings within the provinces of the Emilia-Romagna region leads one to believe that the phenomenon was not limited to the two parishes studied, and shows how said surnames are, still today, among the most frequent in various hill municipalities.

This observation does not challenge what was known regarding the extinction of city families, their continuous replacement by people who immigrated from the countryside and the consequent genetic influx. It is however proof of how, in many cases, it goes side-by-side, thanks to marriages with foundlings entrusted to the care of peasant families, with a limited yet not negligible genetic flow in the other direction. Instead, more important and of considerable impact on the genetic structure of the populations studied, seems to have been the genetic influx connected with immigration that took place in the course of the past one hundred years, coming first from southern Italy and, more recently, also from abroad.

\section{References}

Bussini O. 1991. Gli esposti all'Ospedale della carità di Todi. In: Enfance abandonnée et société en Europe. XIV-XX siècle. École française de Rome. Roma: 301-325.

Corsini C.A. 1976. Materiali per lo studio della famiglia in Toscana nei secoli XVII-XIX: gli esposti. Quad. Storici, 33: 998-1052.

Da Molin G. 1982. Illegittimi ed esposti in Italia dal Seicento all'Ottocento. In: Società Italiana di Demografia Storica. La demografia storica delle cittò italione. CLUEB. Bologna: 497-564.

Di Gaetano C., Guarrera S., Fatibene L., Carturan S., Polidoro S., Vona G., Matullo G., Piazza A. 2001. I polimorfismi biallelici del

\begin{tabular}{|c|c|c|c|c|c|c|c|c|c|c|}
\hline 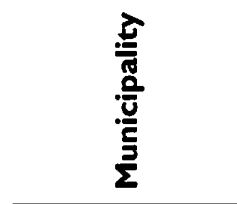 & 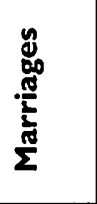 & $\begin{array}{l}\bar{\Phi} \\
\text { ఫु } \\
\text { J }\end{array}$ & 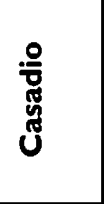 & 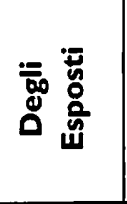 & 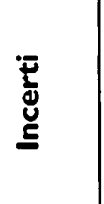 & ז & 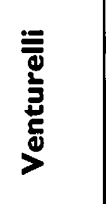 & $\begin{array}{l}\overline{\text { Jँ }} \\
\text { 。 }\end{array}$ & $\begin{array}{l}\frac{0}{\delta} \\
\frac{0}{\sigma} \\
\frac{0}{2}\end{array}$ & 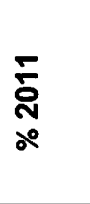 \\
\hline Casalecchio di R. & 436 & 1 & 1 & 10 & 1 & 1 & 1 & 10 & 1.1 & 0.4 \\
\hline Castel d'Aiano & 328 & 1 & 1 & 24 & 1 & 1 & 1 & 24 & 3.7 & 1.8 \\
\hline Formigine & 691 & 1 & 1 & 1 & 6 & 1 & 12 & 18 & 1.3 & 0.5 \\
\hline Gatteo & 308 & 10 & 1 & 1 & 1 & 1 & 1 & 10 & 1.6 & 0.7 \\
\hline Maranello & 404 & 1 & 1 & 1 & 1 & 1 & 20 & 20 & 2.5 & 1.2 \\
\hline San Clemente & 237 & 6 & 1 & 1 & 1 & 1 & 1 & 7 & 1.5 & 0.8 \\
\hline Santarcangelo & 796 & 9 & 1 & 1 & 1 & 1 & 1 & 9 & 0.6 & 0.6 \\
\hline
\end{tabular}

Tab.1. Number of marriages registered, number of parties with characteristic surname, percentage over the total parties in the $1910-19$ period, in the municipalities considered in the sample. The last column shows the percentage of bearers of the characteristic surnames in 2011. With reference to Gatteo there is no data for the year 1914. The number of marriages registered in Castel d'Aiano is an estimated value.

\section{Discussion}

In conclusion, in lggio and Tiola - rural parishes not too far from the cities - it has been possible to notice, with reference to the period that spans between 1820 and 1929 , a large number of marriages between locals and foundlings, marriages that have been able to make up, cromosoma $Y$ usati per lo studio di alcune popolazioni italiane. In:A.A. I., XIV Congresso degli Antropologi Italiani. Croce di Magara - Spezzano Piccolo 25-28/9/2001. Abstracts: 330-331.

Francalacci P., Morelli L., Sanna D. 2006. II popolamento della Sardegna nel contesto mediterraneo. In: Guerci A., Consigliere S., Castagno S. Atti del XVI Congresso degli Antropologi Italiani. Genova 29-31/10/2005. Edicolors Publishing. Milano. 
Kertzer D. 1993. Sacrificed for Honor: Italian Infant Abandonment and the Politics of Reproductive Control. Beacon Press. Boston.

Kertzer D. 1999.Age Structuring and the Lives of Abandoned Children. The History of the Family, 4,1:5-15.

Kertzer D., Koball H.,White M.J. 1997. Growing up as an Abandoned Child in Nineteenth-century Italy. The History of the Fomily, 2, 3:211-228.

Kertzer D., Sigle W. 1998. The Marriage of Female Foundlings in Nineteenth-century Italy. Continuity and Change, 13, 2: 201220.

Mazzoni S., Manfredini M. 2005. Le trovatelle di lggio (Parma). Comportamento nuziale delle esposte dell'Ospedale di Parma nella seconda metà del XIX secolo. Popolazione e Storia, 2/2005: 81-94.

Sanna E., Ghiani E., lovine M. C., Calò C. 2006. Ipotesi sul popolamento della Sardegna e la struttura biologica dei Sardi. In: Guerci A., Consigliere S., Castagno S. Atti del XVI Congresso degli Antropologi Italiani. Genova 29-31/10/2005. Edicolors Publishing. Milano.
Sigle W., Kertzer D., White M.J. 2000.Abandoned Children and their Transition to Adulthood in Nineteenth-century Italy.J. Fom. Hist. 25: 326-340.

Tagliavini F., Nicolini L. 2011. Endogamia, consanguinidad y matrimonios con expósitos en una parroquia de la Montaña Boloñesa. Revista de demografía histórica. nel volume XXIX, I, 2011, segunda época: $163-179$.

Tofanelli S., Bertoneri S., Di Giacomo F., Landucci G., Bonini R., Falsini S., Mela C., Taglioli L., Novelletto A., Paoli G. 2005.Alta frequenza di linee genetiche maschili di origine "pre-agricola" in Garfagnana (Toscana). In: Michetti E., Di Fabrizio A., D'Anastasio R., Capasso L. Atti del XV Congresso dell'Associazione Antropologica Italiana. Chieti 28-30/9/2003. Edigrafital. Sant'Atto: 489-494.

Woods R. 2003. Cities, demographic history of. In: Demeny P., McNicoll G. Encyclopedia of Population. Thomson Gale. New York. 